\title{
STUDI AWAL POTENSI BATUBARA MUARAENIM UNTUK DIKONVERSI MENJADI BAHAN BAKAR CAIR BERDASARKAN KARAKTER BATUBARA
}

\section{PRELIMINARY STUDY OF MUARAENIM COAL POTENTIAL FOR LIQUEFACTION BASED ON COAL CHARACTERISTICS}

\author{
Fatimah \\ Pusat Sumber Daya Mineral Batubara dan Panas Bumi, \\ Jalan Soekarno Hatta No. 444 Bandung \\ liptinita@yahoo.com
}

\section{ABSTRAK}

Formasi Muaraenim merupakan salah satu formasi pembawa batubara di Cekungan Sumatera Selatan yang diendapkan di lingkungan fluvial pada Miosen Akhir - Pliosen Awal. Batubara Formasi Muaraenim umumnya merupakan batubara berperingkat rendah (lignit - subbituminus), kecuali pada beberapa tempat yang terpengaruhi intrusi batuan beku yang menghasilkan batubara antrasit. Metode konversi batubara dapat diterapkan untuk meningkatkan nilai keekonomisan Batubara Muaraenim yang berperingkat rendah. Tujuan studi awal ini adalah untuk mengevaluasi potensi Batubara Muaraenim untuk dikonversi menjadi bahan bakar cair dengan mempertimbangkan karakter batubara (coal properties). Analisis dilakukan terhadap 10 (sepuluh) conto permukaan batubara dan 2 (dua) conto batulempung karbonan dari Formasi Muaraenim dengan parameter analisis TOC, pirolisis Rock Eval, pirolisis Retort, Proksimat, Ultimat dan juga Petrografi Organik. Hasil studi menunjukkan bahwa Batubara Muaraenim sesuai untuk dikonversi menjadi bahan bakar cair.

Kata kunci: bahan bakar cair, Batubara Muaraenim, konversi batubara, karakter batubara

\section{ABSTRACT}

Muaraenim is one of coal bearing formation in South Sumatra Basin, Indonesia. It was deposited on fluviatile environment in Late Miocene-Early Pliocene. The majority of Muaraenim Coal are low in rank (lignite to subbituminous), except some that have been influenced by magmatic intrusion which can reach anthracitic rank. In order to increase the economic value of Muaraenim low rank coal, a conversion method can be applied. Using coal properties analysis, the objective of this preliminary study, is to evaluate the potential of Muaraenim coal to be converted into liquid fuel. Ten coal outcrop as well as two coaly clay samples have been subjected to several laboratory analyses including TOC, Rock Eval pyrolysis, Retort pyrolysis, Proximate, Ultimate, as well as Organic Petrography analyses. Preliminary evaluation indicates a good potential of Muaraenim coal to be converted into liquid fuel.

Keywords: liquid fuel, Muaraenim Coal, Coal Conversion, Coal Properties

\section{PENDAHULUAN}

Kebutuhan dunia akan minyak bumi semakin meningkat seiring dengan pertumbuhan ekonomi dan penduduk dunia. Namun, meningkatnya permintaan minyak bumi ini tidak diimbangi dengan pertumbuhan jumlah cadangan minyak bumi.
Berbagai upaya dilakukan untuk mengantisipasi kemungkinan kurangnya pemenuhan minyak bumi. Salah satunya adalah dengan mengkonversi batubara yang merupakan bahan bakar padat menjadi bahan bakar cair pengganti minyak bumi. Proses ini dikenal dengan istilah "Pencairan Batubara", "Coal Liquefaction" atau "Coal to Liquid / CTL" (Mitchell, dalam Suárez-Ruiz dan Crelling, 2008). 


\section{MAKALAH ILMIAH}

Formasi Muaraenim merupakan salah satu formasi pembawa batubara di Cekungan Sumatera Selatan yang diendapkan di lingkungan fluvial pada Miosen Akhir Pliosen Awal. Batubara Formasi Muaraenim umumnya merupakan batubara berperingkat rendah (lignit - subbituminus), kecuali pada beberapa tempat yang terpengaruhi intrusi batuan beku yang menghasilkan batubara antrasit (Thomas, dalam Barber, et al, 2005). Batubara berperingkat rendah ini kemungkinan dapat ditingkatkan nilai keekonomisannya dengan mengkonversinya menjadi bahan bakar cair (minyak dari batubara). Namun, hal ini memerlukan berbagai kajian yang komprehensif ditinjau dari coal propertiesnya serta teknologi yang sesuai dengan Batubara Muaraenim.

Tulisan ini bertujuan untuk mengkaji kemungkinan batubara Formasi Muaraenim untuk dikonversi menjadi bahan bakar cair ditinjau dari karakter batubara (coal properties)-nya saja. Namun tulisan ini tidak akan membahas kemungkinan jenis teknologi pencairan yang sesuai untuk Batubara Muaraenim.

\section{LOKASI STUDI}

Studi awal ini dilakukan pada conto batubara dari Formasi Muaraenim yang diambil dari daerah Lahat dan Baturaja, Provinsi Sumatera Selatan (Gambar 1). Pemilihan lokasi dengan mempertimbangkan bahwa Sumatera Selatan memiliki potensi batubara yang sangat besar, yaitu $41 \%$ dari batubara Indonesia (Anonim, 2015) namun sampai saat ini belum termanfaatkan secara optimal karena terkendala oleh berbagai hal, misalnya kualitasnya yang kurang bagus (umumnya batubara berperingkat rendah) dan tumpang tindih dengan lahan perkebunan.

\section{METODE}

Studi awal ini dilakukan terhadap 10 (sepuluh) conto batubara Formasi Muaraenim yang diambil dari 2 (dua) lokasi yaitu daerah Lahat dan Baturaja, Provinsi Sumatera Selatan (Gambar 1). Analisis yang dilakukan berupa analisis geokimia batubara (proximate dan ultimate), geokimia hidrokarbon (TOC, Rock Eval Pyrolysis, Pyrolysis Gas Chromatograph, Extraction, Gas Chromatograph), Pyrolysis Retort dan Petrografi Organik.

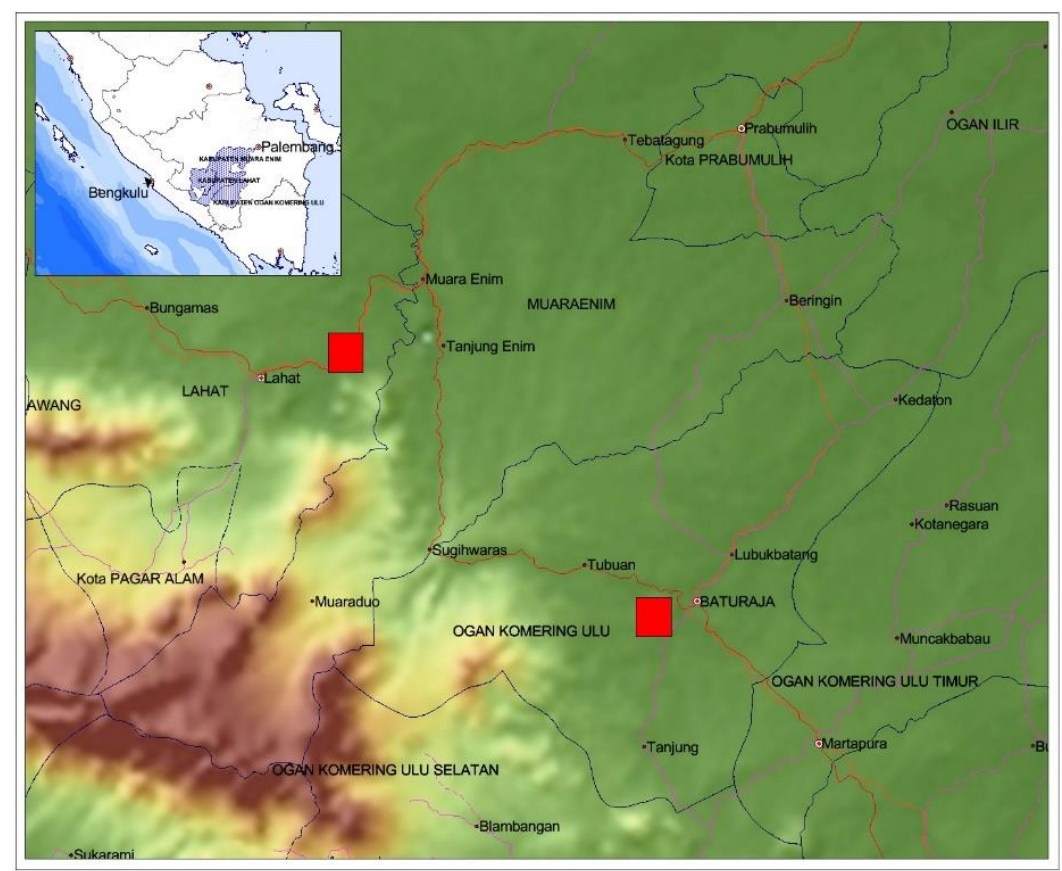

Gambar 1. Lokasi pengambilan conto (noktah merah) 


\section{GEOLOGI REGIONAL}

Cekungan Sumatera Selatan merupakan salah satu cekungan busur belakang (back arch basin) di Pulau Sumatera yang memiliki potensi batubara yang cukup besar (Sapiie, dkk., 2005 - Gambar 2). Secara litologi, Cekungan Sumatera Selatan dan Cekungan Sumatera Tengah memiliki kesamaan sedimentasi batuan; namun kedua cekungan tersebut dipisahkan oleh Tinggian Tigapuluh yang terbentuk akibat pergerakan ulang sesar bongkah pada batuan berumur Pra Tersier diikuti oleh kegiatan volkanik (de Coster, 1974).

Menurut Gafoer, dkk. (1986), sedimentasi Tersier di Cekungan Sumatra Selatan terbagi menjadi dua yaitu Kelompok Telisa dan Kelompok Palembang. Runtunan litologi Kelompok Telisa merupakan satuan batuan yang terbentuk dalam fasa genang laut terdiri atas Formasi Talangakar dan Formasi Gumai. Sebaliknya, Kelompok Palembang terbentuk dalam fasa susut laut yang terdiri atas Formasi Airbenakat, Formasi Muaraenim dan Formasi Kasai.

Formasi pembawa batubara utama di Cekungan Sumatera Selatan adalah
Formasi Muaraenim yang terdiri atas batulempung dengan sisipan batupasir, batubara dan batulanau. Perlapisan sedimennya menunjukkan adanya pengaruh endapan laut tetapi tidak ditemukan adanya fosil foraminifera, kecuali fosil-fosil lamelibranchiata di beberapa tempat (Gafoer, dkk., 1986). Batubara pada Formasi Muaraenim terdiri dari banyak lapisan (multi lapisan) dengan ketebalan berkesinambungan yang cukup tinggi (de Coster, 1974).

Shell Mijnbouw (1978) membagi Formasi Muaraenim menjadi 4 (empat) anggota yaitu M1, M2, M3 dan M4 (Gambar 3). Setiap anggota mengandung paling sedikit 2 (dua) lapisan batubara. Beberapa lapisan juga bertindak sebagai pembatas antar anggota. Beberapa lapisan batubara, misalnya Lapisan Mangus, terbagi menjadi dua lapisan (splitting) pada lokasi-lokasi tertentu. Selain lapisan batubara utama, terdapat juga lapisan-lapisan batubara tipis yang disebut sebagai Lapisan Gantung (Lapisan G). Total ketebalan batubara Formasi Muaraenim di tengah cekungan diperkirakan mencapai 600 meter (Harahap, dkk., 2003).

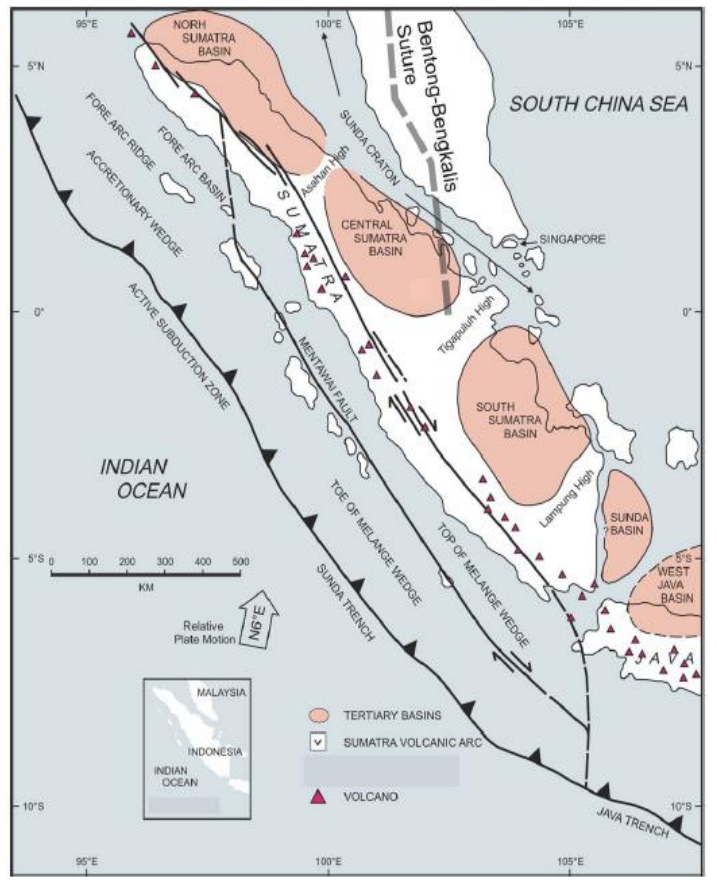

Gambar 2. Cekungan sedimentasi di Pulau Sumatera (Sapiie, dkk., 2005) 


\section{MAKALAH ILMIAH}

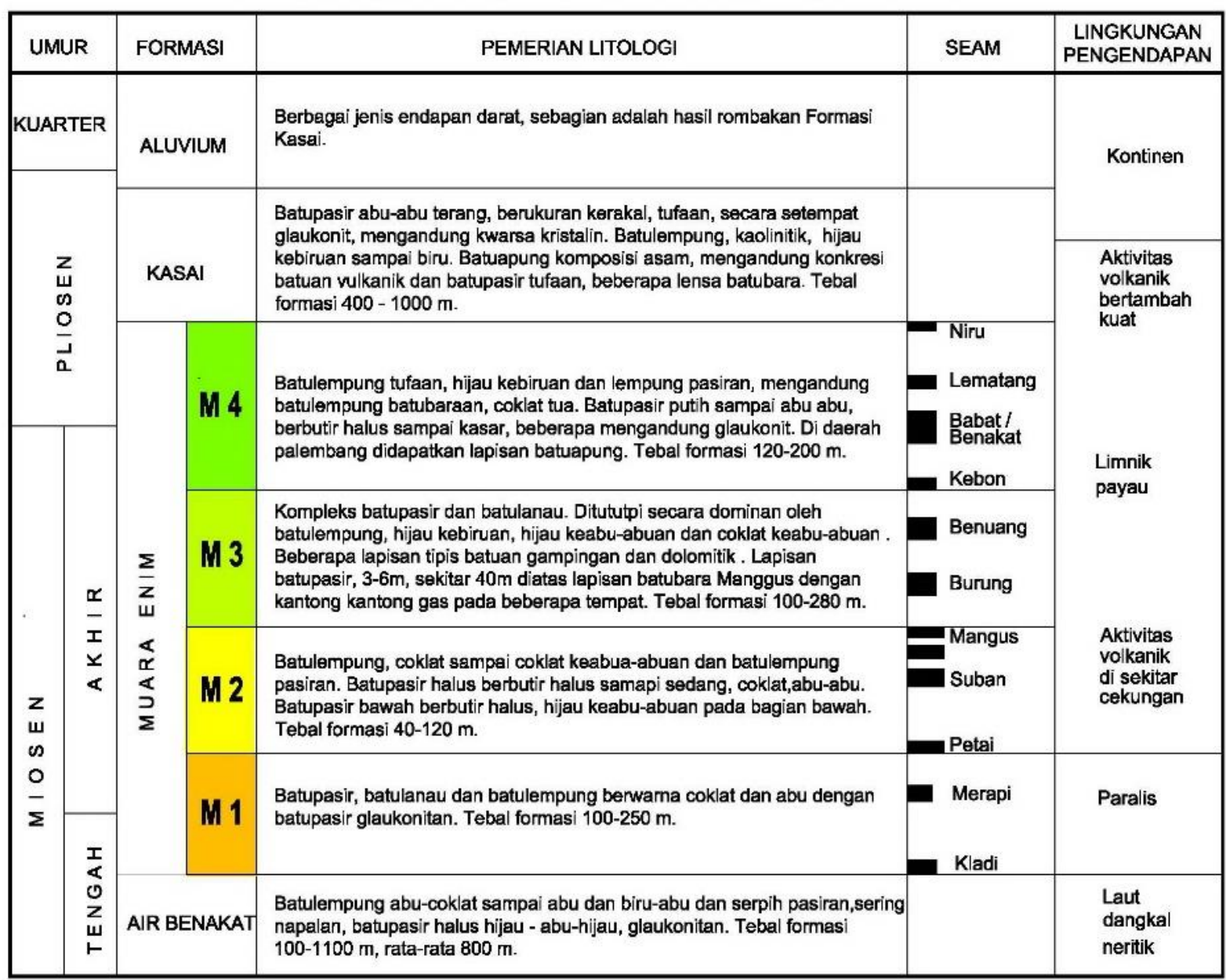

Gambar 3. Stratigrafi Tersier Cekungan Sumatera Selatan dengan penekanan pada pembagian anggota Formasi Muaraenim (modifikasi dari Shell Mijnbouw, 1978)

\section{HASIL DAN PEMBAHASAN}

\section{Analisis Geokimia Batubara}

Hasil analisis geokimia batubara disajikan pada Tabel 1. Conto BRJ-1, BRJ-2A, BRJ2B, BRJ-3, BRJ-4, BRJ-5 dan BRJ-6 berasal dari daerah Baturaja, sedangkan conto CL-1, CCL-2, CCL-3, CL-4 dan CL-5 diambil dari daerah Lahat. Secara stratigrafi conto batubara dari Baturaja merupakan bagian dari Anggota M3 Formasi Muaraenim. Conto batubara dari daerah Baturaja memiliki nilai kalori 4991 $\mathrm{cal} / \mathrm{gr}$ s.d. $5587 \mathrm{cal} / \mathrm{gr}$ adb, batubara dengan kisaran nilai kalori seperti ini dikategorikan sebagai batubara berperingkat rendah (low rank coal). Kandungan abu conto batubara dari Baturaja relatif lebih tinggi dibandingkan conto batubara dari daerah Lahat yaitu $5,28 \%$ adb s.d. $11,61 \%$ adb, namun kandungan sulfur total conto batubara dari Baturaja hampir sama dengan conto Batubara Lahat yaitu $0,40 \%$ adb s.d. $2,28 \% \mathrm{adb}$. 


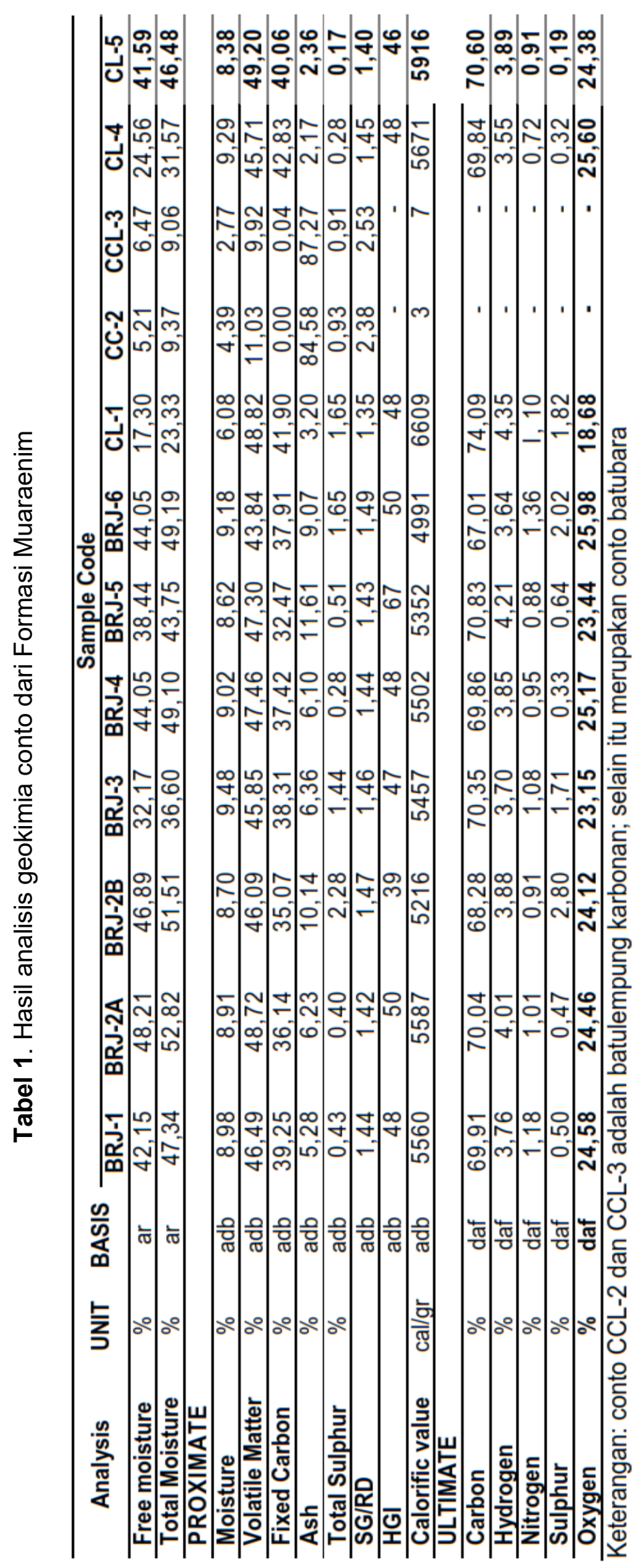


Conto CL-1, CL-4 dan CL-5 merupakan conto batubara dengan nilai kalori 5671 $\mathrm{cal} / \mathrm{gr}$ s.d. $6609 \mathrm{cal} / \mathrm{gr}$, kandungan abu $2,17 \%$ adb s.d. $3,2 \%$ adb, dan kandungan sulfur total $0,17 \%$ adb s.d. $1,65 \%$ adb. Kualitas batubara dari lokasi Lahat dapat dikategorikan sebagai batubara berperingkat rendah-sedang (low-med rank coal) dengan kandungan abu yang relatif rendah. Menurut Thomas (2002), batubara berperingkat rendah (low rank coal) cenderung mengandung hidrogen yang cukup tinggi sehingga dapat menghasilkan lebih banyak bahan bakar cair. Tingginya kandungan hidrogen ini dapat dikonfirmasi dengan analisis organik petrografi. Apabila batubara tersebut mengandung cukup banyak maseral liptinit maka dapat diasumsikan batubara tersebut memiliki kandungan hidrogen yang cukup banyak pula.

Conto CCL-2 dan CCL-3 merupakan conto lempung karbonan. Conto CCL-2 berasal dari lapisan atas (roof) Lapisan A1 atau Lapisan Mangus. Sedangkan conto CCL-3 adalah lapisan lempung karbonan yang diambil dari lapisan antara Lapisan Suban dan Lapisan Petai (interburden). Lapisan Mangus, Lapisan Suban dan Lapisan Petai merupakan Anggota M2 dari Formasi Muaraenim (Gambar 2). Batulempung karbonan merupakan batulempung yang memiliki kandungan organik cukup banyak. Tujuan pengambilan conto batulempung karbonan ini yaitu untuk mengamati karakter mikroskopis dari batuan ini baik secara komposisi dan kandungannya untuk kemudian dibandingkan dengan karakter batubaranya. Asumsi sementara, kandungan organik yang cukup banyak dapat menghasilkan minyak apabila batuan tersebut dipanaskan pada suhu minimal $550^{\circ} \mathrm{C}$ yaitu dengan proses retorting ataupun pyrolisis. Namun tentu saja karakter lainnya harus diamati juga, misalnya komposisi organiknya, kandungan abu, sulfur, dan lain-lain.

Conto batulempung karbonan CCL-2 dan CCL-3 memiliki nilai kalori yang sangat rendah, karena conto ini didominasi oleh batulempung dengan sedikit karbon sehingga tidak memiliki kemampuan menghasilkan panas. Namun harus dilihat juga komposisi material organik yang ada pada batulempung tersebut. Apabila material organiknya didominasi oleh maseral liptinit, maka kemungkinan besar conto tersebut akan menghasilkan cukup banyak minyak apabila dilakukan proses retorting.

\section{Analisis Geokimia Hidrokarbon}

Analisis geokimia hidrokarbon meliputi karbon organik total (Total Organic Carbon / TOC), pirolisis rock eval, pirolisis kromatografi gas (pyrolysis chromatograph gas / PY-GC) dan kromatografi gas (Gas Chromatograph / GC). Analisis TOC dilakukan terhadap semua conto (12 conto) baik batubara maupun batulempung karbonan, dari hasil analisis TOC kemudian dilakukan analisis Pirolisis Rock Eval sebanyak 10 conto, Prirolisis GC sebanyak 4 conto, Ekstraksi sebanyak 4 conto dan Kromatografi Gas sebanyak 4 conto (Tabel 2).

Hasil analisis TOC dan Rock-Eval Pyrolysis disajikan pada Tabel 3. Kandungan TOC conto Batubara Lahat relatif sama yaitu 60,26 wt $\%$ s.d. 62,46 wt\%. Conto Batubara Baturaja memiliki kandungan TOC yang sedikit lebih rendah dibandingkan Batubara Lahat yaitu 45,71 wt $\%$ s.d. 58,58 wt $\%$. Sedangkan conto batulempung karbonan memiliki kandungan TOC yang sangat rendah yaitu 1,78 wt $\%$ s.d. 2,19 wt $\%$, hal ini sangatlah wajar karena memang umumnya kandungan karbon pada batulempung jauh lebih rendah dibandingkan pada batubara. Peter dan Moldowan (1993) menyatakan bahwa batuan induk yang sangat baik memiliki kandungan TOC minimal 5\%wt, oleh karena itu dapat disimpulkan bahwa seluruh conto batubara baik yang diambil dari Lahat maupun Baturaja, dapat dikategorikan sebagai batuan induk yang sangat baik. Akan halnya conto batulempung karbonan dari Lahat (conto CCL-2 dan CCL-3) tidak dapat dikategorikan sebagai batuan induk. 
Tabel 2. Jenis analisis geokimia hidrokarbon yang dilakukan

\begin{tabular}{lccrcrc}
\hline Conto & Jenis Batuan & TOC & Rock Eval & PY-GC & Ekstraksi & GC \\
\hline CL-1 & Batubara & $\sqrt{ }$ & $\sqrt{ }$ & $\sqrt{ }$ & $\sqrt{ }$ & $\sqrt{ }$ \\
\hline CL-4 & Batubara & $\sqrt{ }$ & $\sqrt{ }$ & - & - & - \\
\hline CL-5 & Batubara & $\sqrt{ }$ & $\sqrt{ }$ & - & - & - \\
\hline CCL-2 & Batulempung karbonan & $\sqrt{ }$ & $\sqrt{ }$ & - & - & - \\
\hline CCL-3 & Batulempung karbonan & $\sqrt{ }$ & $\sqrt{ }$ & $\sqrt{ }$ & $\sqrt{ }$ & $\sqrt{ }$ \\
\hline BRJ-1 & Batubara & $\sqrt{ }$ & $\sqrt{ }$ & - & - & - \\
\hline BRJ-2A & Batubara & $\sqrt{ }$ & $\sqrt{ }$ & $\sqrt{ }$ & $\sqrt{ }$ & $\sqrt{ }$ \\
\hline BRJ-2B & Batubara & $\sqrt{ }$ & - & - & - & - \\
\hline BRJ-3 & Batubara & $\sqrt{ }$ & $\sqrt{ }$ & - & - & - \\
\hline BRJ-4 & Batubara & $\sqrt{ }$ & $\sqrt{ }$ & $\sqrt{ }$ & $\sqrt{ }$ & $\sqrt{ }$ \\
\hline BRJ-5 & Batubara & $\sqrt{ }$ & $\sqrt{ }$ & - & - & - \\
\hline BRJ-6 & Batubara & $\sqrt{ }$ & - & - & - & - \\
\hline
\end{tabular}

Tabel 3. Hasil analisis TOC dan Rock-Eval Pyrolysis

\begin{tabular}{|c|c|c|c|c|c|c|c|}
\hline \multirow[t]{2}{*}{ Sample ID } & \multirow{2}{*}{$\begin{array}{l}\text { TOC } \\
\text { (wt\%) }\end{array}$} & $S_{1}$ & $\mathrm{~S}_{2}$ & $\mathrm{~S}_{3}$ & \multirow{2}{*}{$\begin{array}{l}\mathrm{T}_{\max } \\
\left({ }^{\circ} \mathrm{C}\right)\end{array}$} & \multirow[t]{2}{*}{$\mathrm{HI}$} & \multirow[t]{2}{*}{ Ol } \\
\hline & & \multicolumn{3}{|c|}{$\mathrm{mg} / \mathrm{gr}$ rock } & & & \\
\hline CL-1 & 62,46 & 29,40 & 602,71 & 33,05 & 397 & 965 & 53 \\
\hline CL-4 & 60,57 & 0,53 & 12,51 & 4,80 & 403 & 21 & 8 \\
\hline CL-5 & 60,26 & 5,45 & 144,21 & 29,58 & 408 & 239 & 49 \\
\hline CCL-2 & 2,19 & 0,17 & 1,75 & 0,16 & 425 & 80 & 7 \\
\hline CCL-3 & 1,78 & 0,20 & 1,74 & 0,06 & 422 & 98 & 3 \\
\hline BRJ-1 & 57,73 & 1,51 & 86,51 & 25,53 & 411 & 150 & 44 \\
\hline BRJ-2A & 45,71 & 2,89 & 87,71 & 26,49 & 392 & 192 & 58 \\
\hline BRJ-2B & 54,33 & - & - & - & - & - & - \\
\hline BRJ-3 & 58,58 & 2,54 & 91,90 & 30,90 & 409 & 157 & 53 \\
\hline BRJ-4 & 51,32 & 3,10 & 101,84 & 24,36 & 405 & 198 & 47 \\
\hline BRJ-5 & 55,71 & 2,01 & 79,90 & 22,88 & 403 & 143 & 41 \\
\hline BRJ-6 & 57,50 & & - & - & - & - & - \\
\hline
\end{tabular}

Keterangan: $\quad \mathrm{HI}=$ Hydrogen Index

OI = Oxygen Index

Kandungan hidrokarbon bebas $\left(\mathrm{S}_{1}\right)$ pada conto Batubara Lahat menunjukkan perbedaan yang cukup signifikan. Conto CL-1 memiliki kandungan hidrokarbon bebas sebesar 29,40 mg/gr sementara conto CL-4 dan CL-5 hanya memiliki kandungan hidrokarbon bebas sebesar $0,53 \mathrm{mg} / \mathrm{gr}$ dan $5.45 \mathrm{mg} / \mathrm{gr}$. Hasil analisis ultimat (Tabel 1) mengkonfirmasi perbedaan ini. Kandungan karbon dan hidrogen conto CL-1 yang diperoleh dari analisis ultimat menunjukkan nilai yang lebih tinggi dibandingkan conto $\mathrm{CL}-4$ dan CL-5. Secara stratigrafi perbedaan ini juga memungkinkan mengingat conto $\mathrm{CL}-1$ merupakan batubara Anggota M2 sedangkan conto CL-4 dan CL-5 merupakan Anggota M4 yang posisi stratigrafinya lebih atas (lebih muda) dalam Formasi Muaraenim.

Conto Batubara Baturaja menunjukkan kandungan hidrokarbon bebas yang hampir sama $(1,51 \mathrm{mg} / \mathrm{gr}$ s.d. 3,10 $\mathrm{mg} / \mathrm{gr})$. Sedangkan conto batulempung karbonan menunjukkan nilai yang sangat rendah $(0,17 \mathrm{mg} / \mathrm{gr}$ dan $0.20 \mathrm{mg} / \mathrm{gr})$.

Evaluasi potensi batuan induk dilakukan berdasarkan data TOC dan Rock-Eval pyrolysis (Gambar 3 s.d. Gambar 6). Hasil analisis menunjukkan bahwa conto batuan mengandung karbon organik dengan kualitas antara 'baik' sampai 'sangat baik' $(1,78 \%$ s.d. $2,19 \%)$ untuk conto CCL-2 dan CCL-3. Analisis pirolisis terhadap kedua 


\section{MAKALAH ILMIAH}

conto tersebut menunjukkan nilai $S_{2}$ yang sangat rendah $(1,74 \mathrm{mg} / \mathrm{g}$ s.d. $1,75 \mathrm{mg} / \mathrm{g})$, jauh di bawah ambang nilai komersial 4 $\mathrm{mg} / \mathrm{g}$ batuan. Data kematangan termal yang dapat digunakan berdasarkan nilai $\mathrm{T}_{\max }\left(422^{\circ} \mathrm{C}\right.$ s.d. $\left.425^{\circ} \mathrm{C}\right)$ memberikan indikasi conto batuan yang dianalisis masih dalam tingkatan belum matang bagi pembentukan minyak bumi. Pada tingkat kematangan termal tinggi, conto batuan tersebut diperkirakan hanya berpotensi rendah sebagai penghasil gas. Nilai kandungan hidrogen $(\mathrm{HI})$ yang rendah di bawah $100 \mathrm{mg} / \mathrm{g}$ TOC menunjukkan kandungan bahan organik Tipe III / IV yang berasal dari tumbuhan darat.

Conto batubara umumnya menunjukkan kisaran nilai karbon organik dengan variasi antara $\quad 45 \% \quad$ s.d. $\quad 62 \%$ yang mengindikasikan batubara berperingkat rendah (low rank coal). Hasil analisis pirolisis menunjukkan kandungan bahan organik dengan variasi nilai antara terendah pada conto $\mathrm{CL}-4 \quad\left(\mathrm{~S}_{2}=12.51\right.$ $\mathrm{mg} / \mathrm{g})$ dan tertinggi pada conto $\mathrm{CL}-1\left(\mathrm{~S}_{2}=\right.$ $602.71 \mathrm{mg} / \mathrm{g}$ ). Terkecuali conto CL-1 dan CL-5, seluruh conto batubara dikategorikan sebagai penghasil gas yang baik apabila mencapai tingkat kematangan termal tinggi bagi pembentukan minyak bumi karena kandungan hidrogennya yang sangat rendah $(\mathrm{HI}<200 \mathrm{mg} / \mathrm{g}$ TOC). Pada kondisi saat ini, seluruh conto batubara masih berada pada tingkat kematangan termal yang rendah seperti ditunjukkan nilai $\mathrm{T}_{\max }$ antara $397^{\circ} \mathrm{C}$ s.d. $422^{\circ} \mathrm{C}$. Kelimpahan kandungan hidrokarbon $\left(\mathrm{S}_{2}\right)$ yang sangat tinggi pada batubara $\mathrm{CL}-1\left(\mathrm{~S}_{2}=602.71\right.$ $\mathrm{mg} / \mathrm{g}$ ) merupakan pengecualian. Hal ini mungkin dikarenakan posisi stratigrafi conto CL-1 yang lebih dalam / lebih tua dibandingkan conto lainnya. Kandungan hidrogen yang tinggi pada batubara CL-1 $(\mathrm{HI}=965 \mathrm{mg} / \mathrm{g} \mathrm{TOC})$ mengindikasikan batubara tersebut berpotensi sebagai penghasil minyak apabila mencapai tingkat kematangan tinggi karena kandungan bahan organik sapropelik (kerogen Tipe I). Conto batubara lainnya dengan kandungan hidrokarbon cukup tinggi adalah CL-5 $\left(\mathrm{S}_{2}=\right.$ $144.21 \mathrm{mg} / \mathrm{g}$ ) yang juga mengandung kerogen liptinite seperti ditunjukkan oleh nilai $\mathrm{HI}=239 \mathrm{mg} / \mathrm{g}$ TOC. Meskipun demikian, batubara tersebut tidak cukup berpotensi sebagai penghasil minyak melainkan gas pada tingkat kematangan termal tinggi. Pada umumnya, batubara yang menghasilkan minyak bumi di Indonesia mempunyai kisaran kandungan hidrokarbon $\left(S_{2}\right)$ lebih dari $200 \mathrm{mg} / \mathrm{g}$ dengan kerogen sapropelik (Tipe II / I).
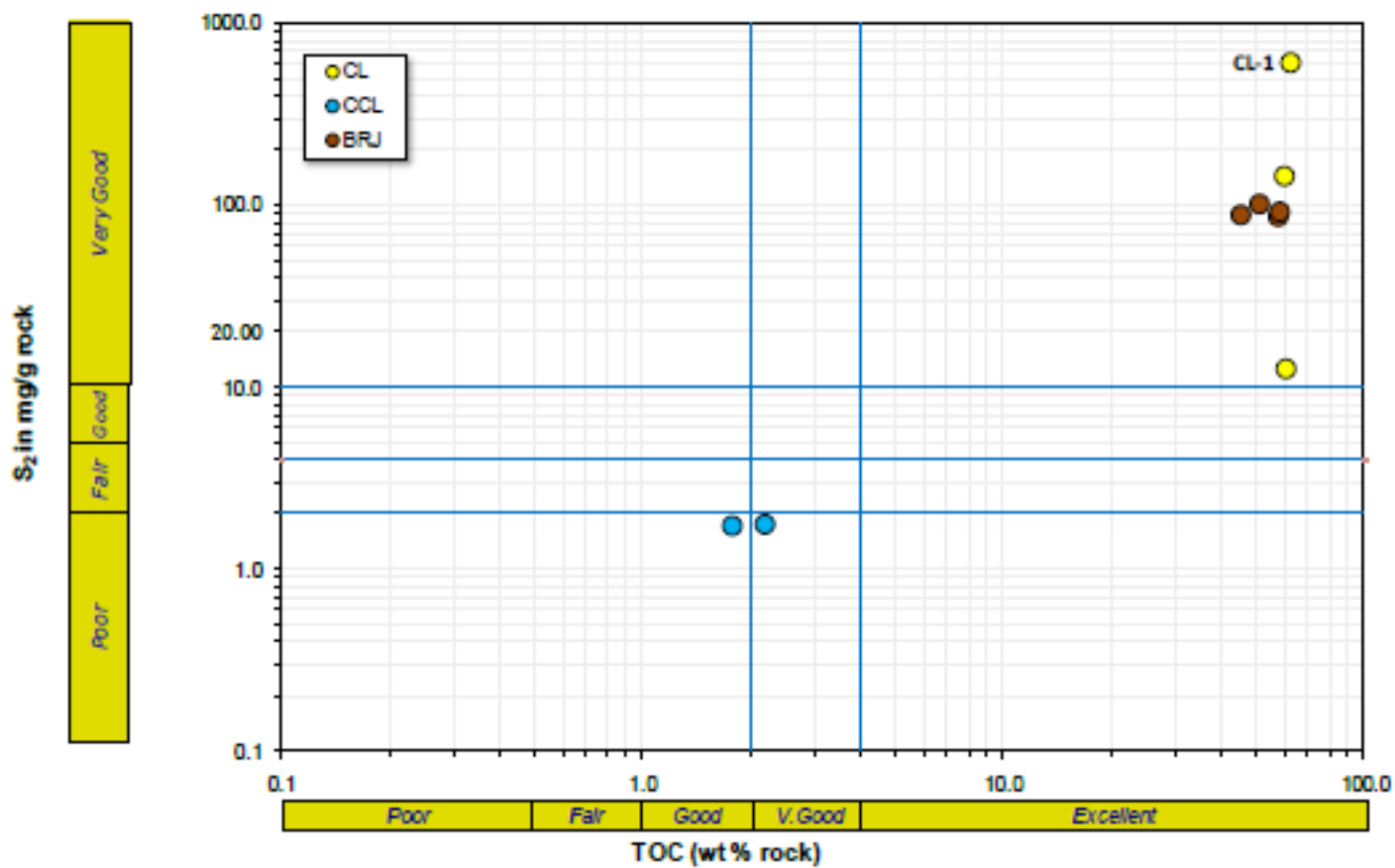

Gambar 3. Plot TOC terhadap kelimpahan bahan organik $\left(\mathrm{S}_{2}\right)$ 


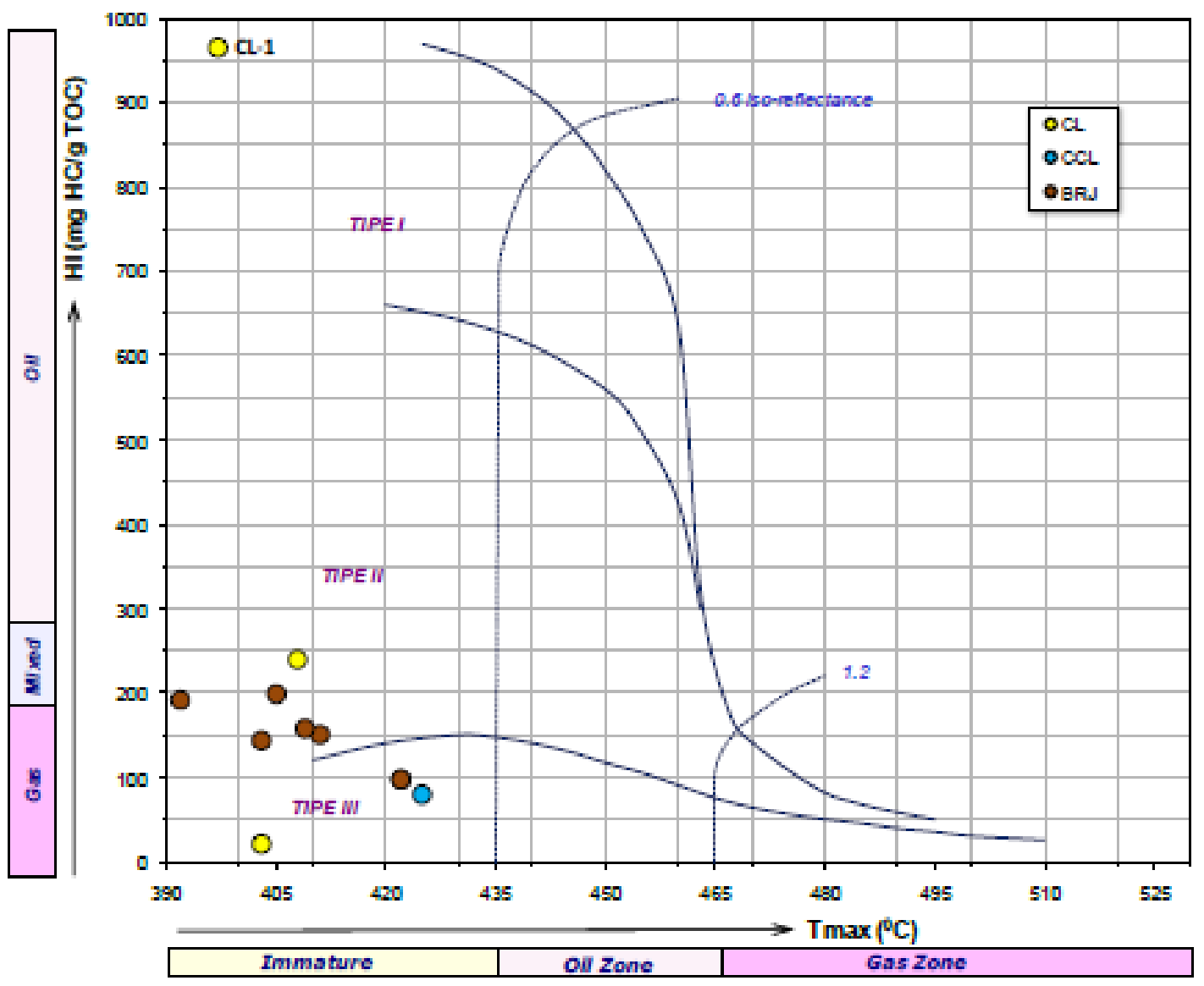

Gambar 4. Plot $\mathrm{T}_{\max }$ terhadap kandungan Hidrogen $(\mathrm{HI})$

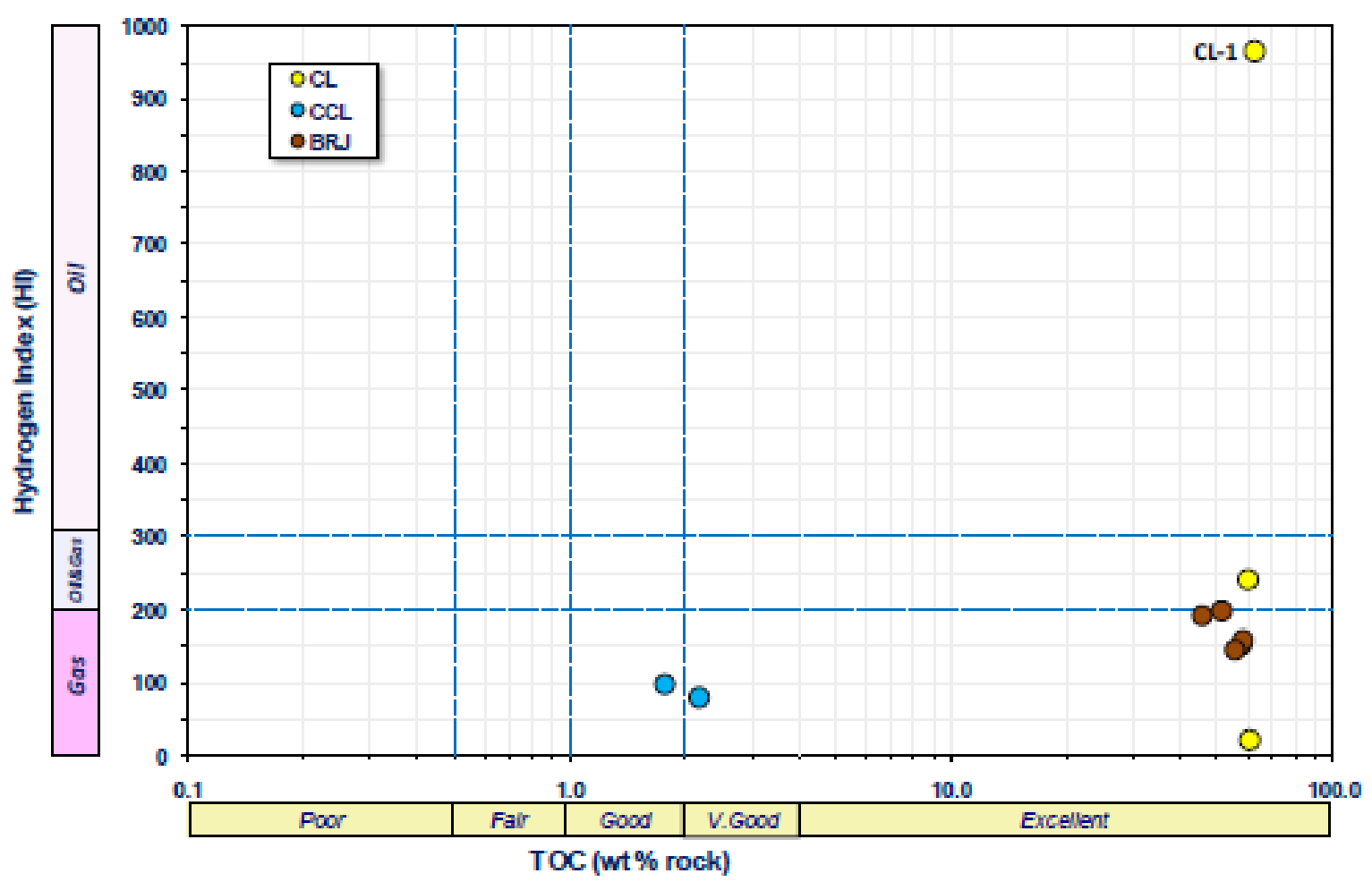

Gambar 5. Plot TOC terhadap kandungan hidrogen $(\mathrm{HI})$ untuk penentuan potensi hidrokarbon 


\section{MAKALAH ILMIAH}

Analisis pirolisis kromatografi gas (Pyrolysis Gas Chromatograph / PY GC) dilakukan terhadap conto CL-1, CCL-3, BRJ-2A dan BRJ-4 (Tabel 4). Hasil PY-GC memperlihatkan bahwa terkecuali conto batulempung karbonan CCL-3, conto batubara mengandung hidrokarbon dengan komposisi fraksi minyak (C6+) lebih dominan dibandingkan dengan fraksi gas (C1-C5). Conto CL-1 memiliki kandungan minyak paling tinggi ( $81 \%)$. Batulempung karbonan CCL-3 menunjukkan kandungan hidrokarbon gas dalam jumlah sedikit di bawah fraksi minyak ( 46\%). Meskipun demikian, kandungan n-octane yang rendah menunjukkan bahwa bahan organik terkandung di dalam conto batulempung karbonan dan batubara berasal dari unsurunsur tumbuhan darat yang banyak mengandung senyawa-senyawa aromatik seperti phenol dan $m+p$ Xylene yang cukup tinggi (Tabel 5). Diagram segitiga (Gambar 7) memperlihatkan seluruh conto mengandung kerogen Tipe III yang banyak dijumpai pada batubara terestrial. Hasil analisis ini tidak sesuai dengan data yang diperoleh dari analisis Rock-Eval Pyrolysis. Hal ini kemungkinan disebabkan adanya kontaminasi pada conto batubara. Kemungkinan lainnya adalah batubara banyak mengandung senyawa resin yang banyak menghasilkan hidrokarbon fraksi berat meskipun pada tingkat kematangan termal yang rendah.

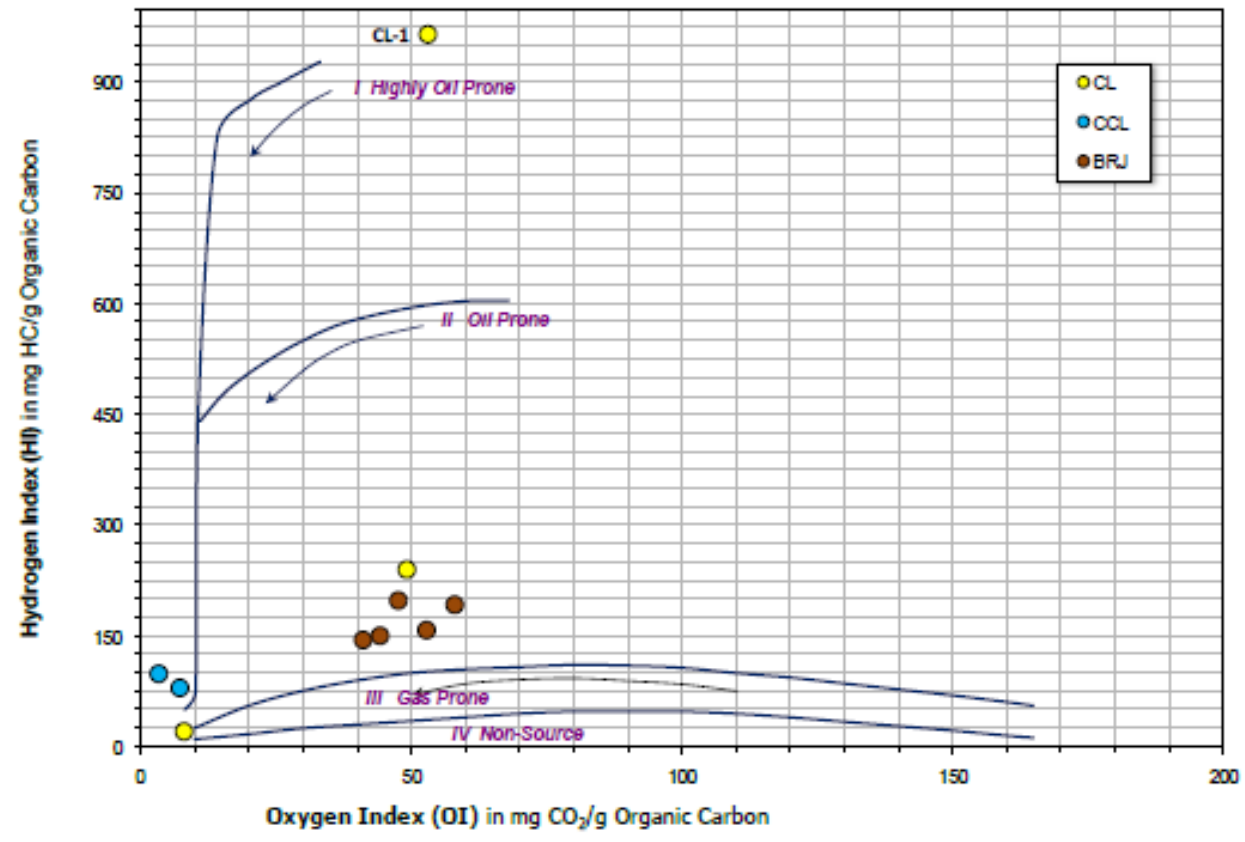

Gambar 6. Plot TOC terhadap kandungan $\mathrm{HI}$ untuk penentuan tipe material organik

Tabel 4. Hasil analisis PY GC (\% Total Hidrokarbon)

\begin{tabular}{crrrrrr}
\hline Sample & $\mathbf{C}_{\mathbf{1}}-\mathbf{C}_{\mathbf{5}}$ & \multicolumn{1}{c}{$\mathbf{C}_{\mathbf{6}}-\mathbf{C}_{\mathbf{9}}$} & $\mathbf{C}_{10}-\mathbf{C}_{13}$ & $\mathbf{C}_{14}-\mathbf{C}_{\mathbf{2 2}}$ & $\boldsymbol{>}_{\mathbf{2 3}}$ & \multicolumn{1}{c}{ Total } \\
\hline CL-1 & 19,26 & 15,27 & 18,13 & 25,72 & 21,62 & 100,00 \\
\hline CCL-3 & 45,93 & 34,29 & 12,86 & 6,92 & 0,00 & 100,00 \\
\hline BRJ-2A & 23,29 & 19,35 & 16,65 & 23,81 & 16,91 & 100,00 \\
\hline BRJ-4 & 28,17 & 17,14 & 15,53 & 23,71 & 15,44 & 100,00
\end{tabular}

Tabel 5. Relative distribution of n-octene, $(m+p)$-Xylenes and phenol in $550^{\circ} \mathrm{C}$ on whole rock pyrolysates

\begin{tabular}{ccccc}
\hline Sample & $\mathbf{N}-$ Octene $\mathbf{( \% )}$ & $\mathbf{( m + p ) - X y l e n e s ~ ( \% )}$ & Phenol (\%) & Carbon Range \\
\hline CL-1 & 19,63 & 69,21 & 11,16 & $\mathrm{C}_{5}-\mathrm{C}_{35}$ \\
\hline CCL-3 & 16,22 & 73,90 & 9,89 & $\mathrm{C}_{5}-\mathrm{C}_{22}$ \\
\hline BRJ-2A & 18,96 & 66,69 & 14,35 & $\mathrm{C}_{5}-\mathrm{C}_{35}$ \\
\hline BRJ-4 & 17,54 & 70,85 & 11,61 & $\mathrm{C}_{5}-\mathrm{C}_{35}$ \\
\hline
\end{tabular}


Hasil ekstraksi conto batubara CL-1, BRJ2A dan BRJ-4 menunjukkan jumlah material organik yang dapat diekstraksi (Extractable Organic Matter / EOM) yang tinggi (48.000 - 103.000 ppm), sedangkan batulempung karbonan CCL-3 mempunyai nilai EOM yang cukup baik (1.500 ppm) seperti yang ditunjukkan pada Tabel 6 dan Gambar 8. Meskipun demikian, rasio HC/TOC dari seluruh conto ekstrak batuan menunjukkan nilai yang sangat rendah (1 - $25 \mathrm{mg} / \mathrm{g}$ TOC) yang menunjukkan kondisi kematangan termal rendah sehingga hidrokarbon yang terbentuk sangat rendah jumlahnya. Tabel 6 memperlihatkan ekstrak dari conto batulempung karbonan maupun batubara mengandung senyawa-senyawa nonhidrokarbon yang sangat dominan dari produk kematangan termal rendah.

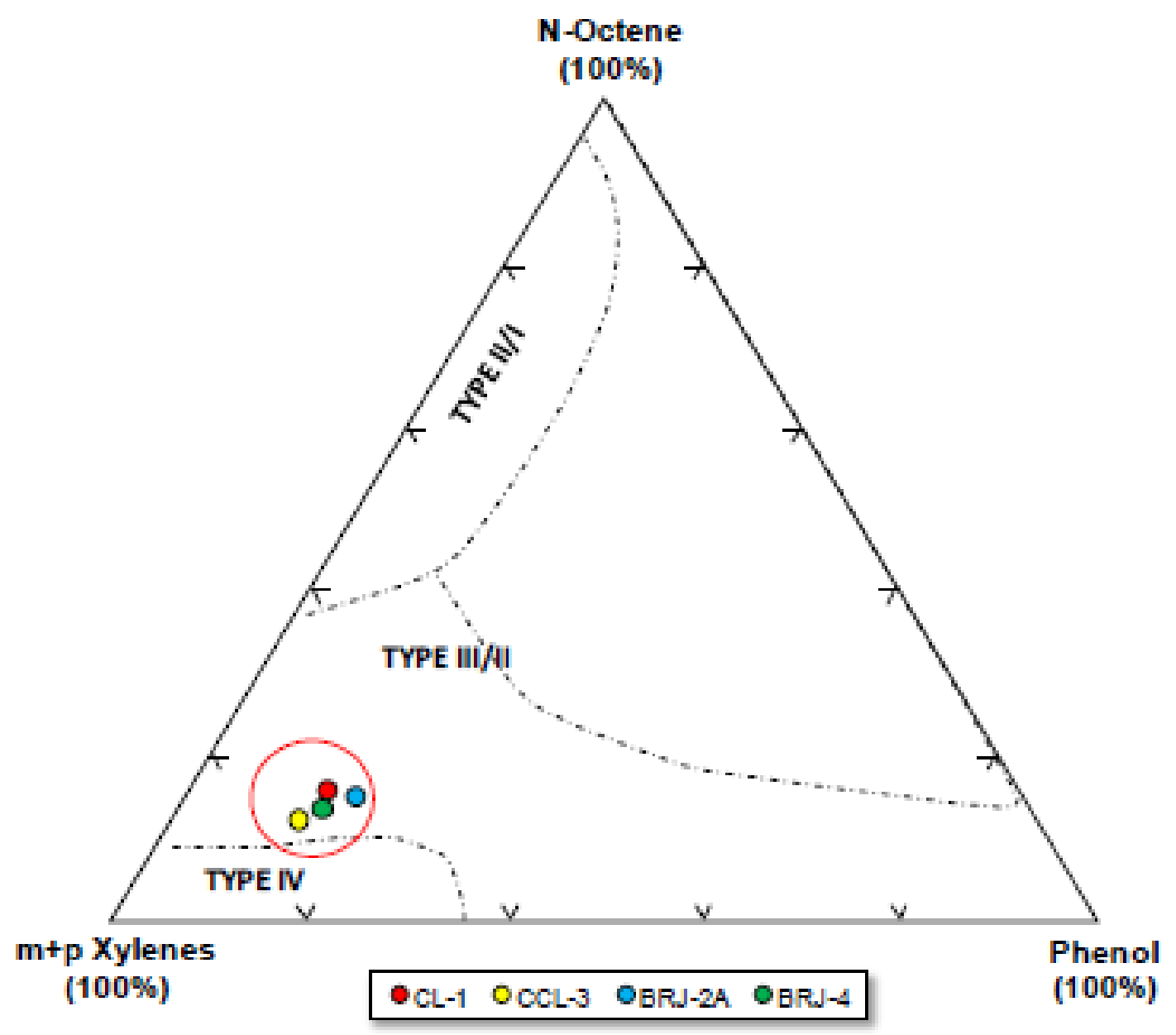

Gambar 7. Plot setiap conto pada diagram segitiga $n$-Octene, $m+p$ Xylenes dan Phenol

Tabel 6. Bitumen Composition and Gas Chromatography Data

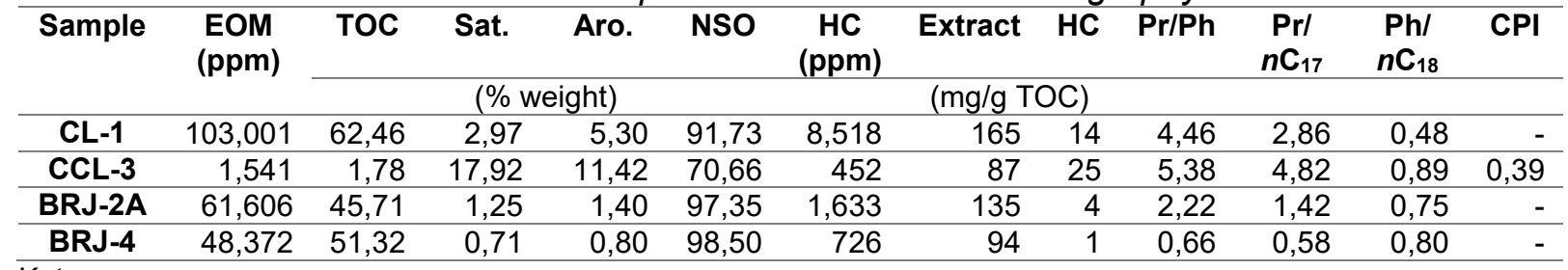

Keteranga:

EOM : Extractable Organic Matter - gram bitumen/gram sample x 106 (ppm)

TOC : Total Organic Carbon (\% wt)

Sat : Saturated Fraction

Aro : Aromatic Fraction

NSO : Non Polars Fraction 


\section{MAKALAH ILMIAH}

Sidik jari kromatografi gas dari keempat ekstrak batuan ditandai dengan pembentukan $n$-alkana yang sangat rendah serta keberadaan senyawasenyawa tak terurai (gugus naftan) sangat dominan (Gambar 9). Konfigurasi gas kromatogram seperti ini lazim dijumpai pada ekstrak batuan dengan tingkat kematangan termal sangat rendah. Pada tingkat kematangan yang sangat rendah ini

pembentukan senyawa-senyawa isoprenoid juga belum optimal sehingga parameter-parameter $\mathrm{pr} / \mathrm{ph}, \quad \mathrm{pr} / \mathrm{nC}_{17}$, $\mathrm{ph} / n \mathrm{C}_{18}$ maupun $\mathrm{CPI}$ tidak dapat dipergunakan secara pasti karena senyawa-senyawa tersebut belum mencapai fasa pembentukan maksimal. Plot nilai rasio $\mathrm{pr} / n \mathrm{C}_{17}$ terhadap $\mathrm{ph} / n \mathrm{C}_{18}$ (Gambar 10) hanya dapat dipergunakan dengan berbagai perimbangan.

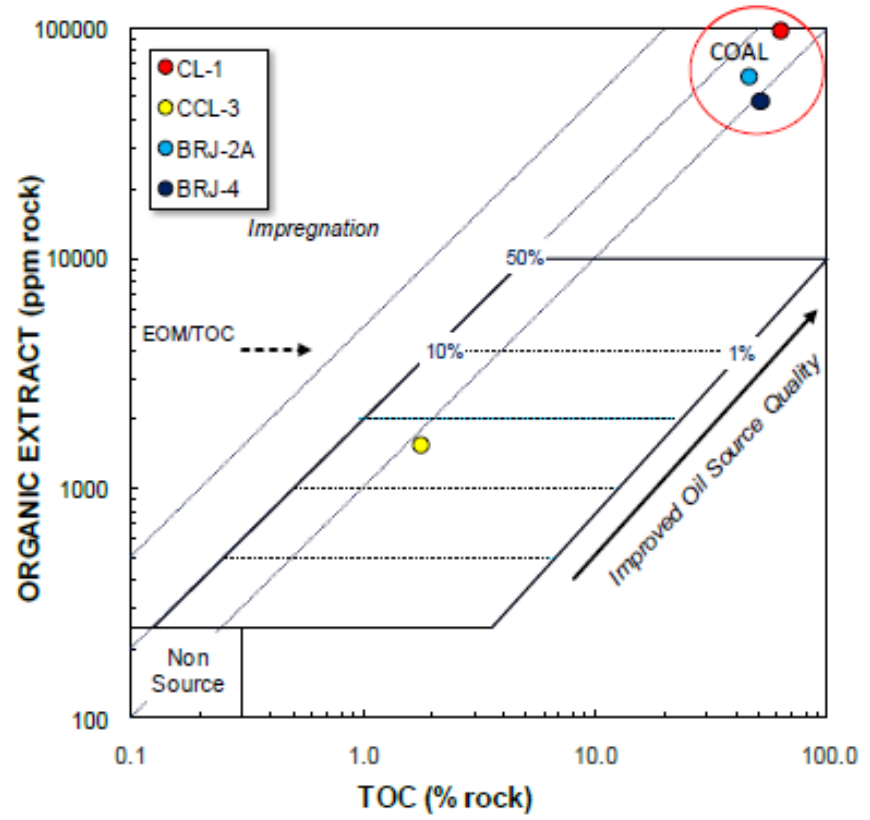

Gambar 8. Plot kandungan karbon organik terhadap ekstrak conto batuan

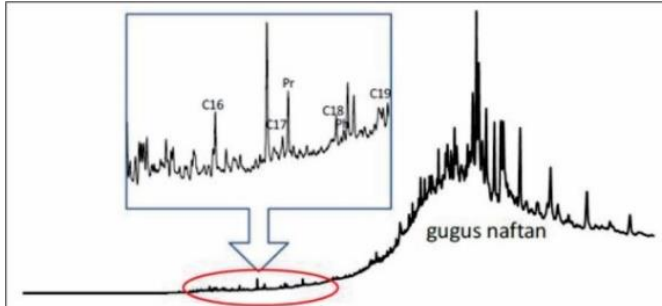

(a)

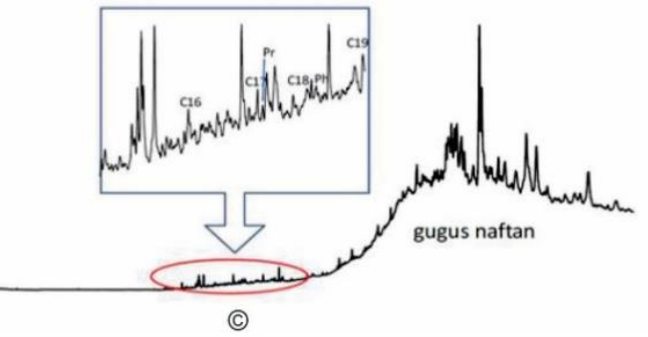

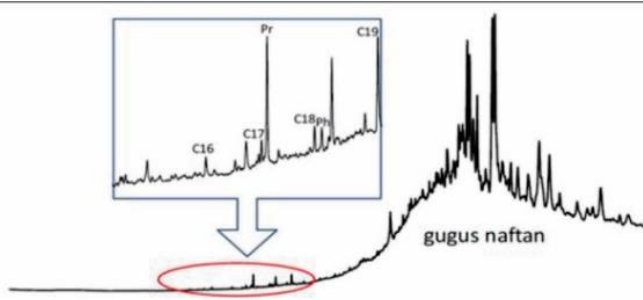

(b)

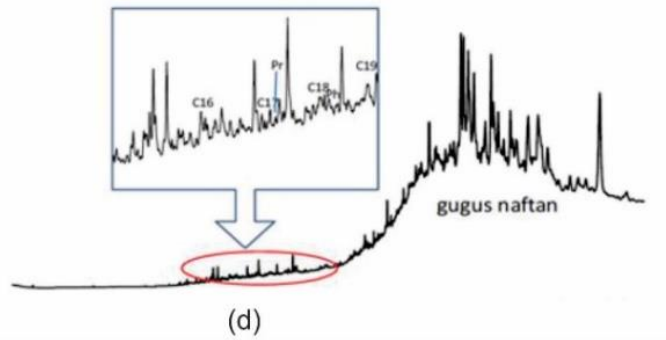

(d)

Gambar 9. Sidik jari ion kromatogram gas conto batubara CL-1 (a), conto batulempung karbonan CCL-3 (b), conto batubara BRJ-2A (c) dan conto batubara BRJ-4 (d), menunjukkan dominasi gugus naftan 


\section{Analisis Pirolisis Retort}

Analisis pirolisis retort merupakan analisis yang dilakukan untuk mengetahui kandungan minyak pada batuan dengan cara memanaskan conto batuan tersebut pada suhu minimum $550^{\circ} \mathrm{C}$. Pemanasan pada suhu tersebut akan merubah material organik yang terkandung pada conto batuan dari fase padat menjadi hidrokarbon cair atau minyak. Analisis retort dilakukan pada seluruh conto sebanyak 12 (dua belas) conto (Tabel 7)

Hasil analisis pirolisis retort menunjukkan kandungan minyak yang cukup signifikan pada seluruh conto batubara. Kandungan minyak dari Batubara Lahat sebesar
30 l/ton s.d. $60 \mathrm{l} /$ ton, sedangkan kandungan minyak Batubara Baturaja sebesar 20 l/ton s.d. 50 I/ton. Sementara conto batulempung karbonan (kode conto CCL-2 dan CCL-3) hanya mengandung minyak sebesar $5 \mathrm{l} /$ ton s.d. $10 \mathrm{l} / \mathrm{ton}$. Hal ini kemungkinan disebabkan oleh rendahnya kandungan material organik pada conto batulempung karbonan tersebut, hal ini juga dikonfirmasi dengan hasil analisis organik petrografi (Tabel 8).

\section{Analisis Petrografi Organik}

Analisis Petrografi Organik dilakukan terhadap 12 (dua belas) conto batubara dan batuan dari Lahat dan Baturaja (Tabel 8).

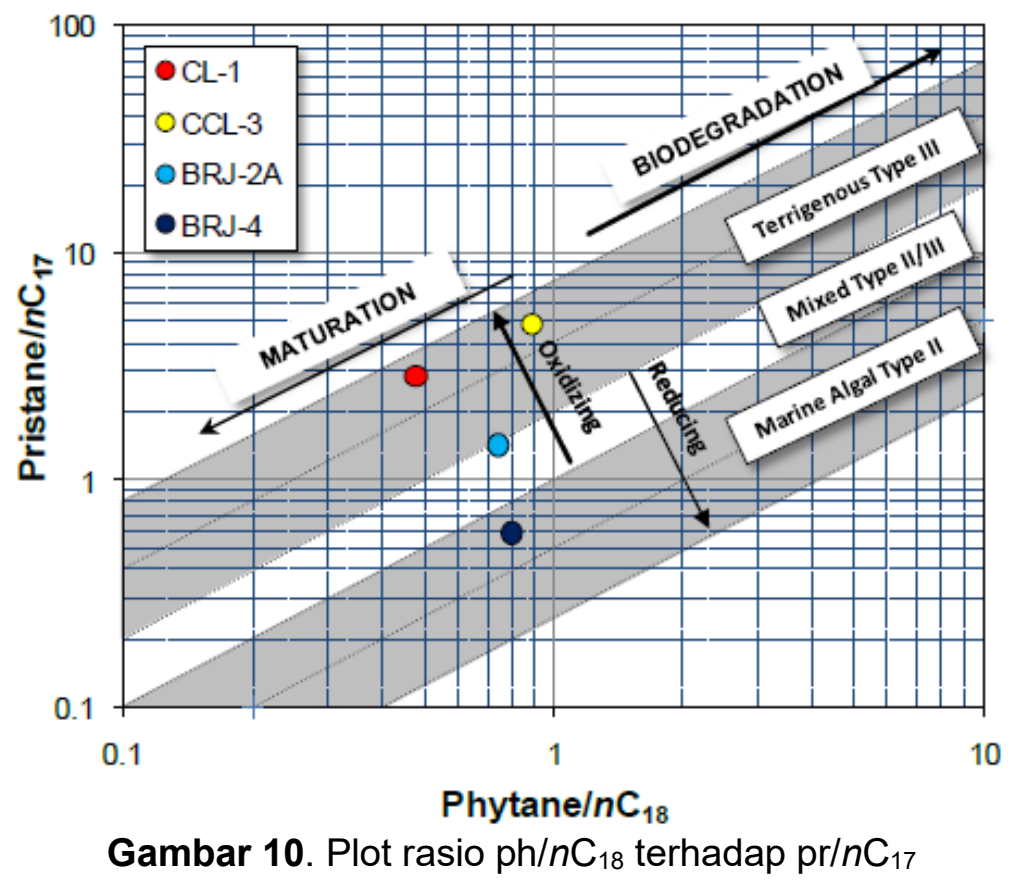

Tabel 7. Hasil analisis pirolisis retort conto batuan Lahat dan Baturaja

\begin{tabular}{ccrr}
\multirow{2}{*}{ NO } & \multirow{2}{*}{ Nomor Conto } & \multicolumn{2}{c}{ KANDUNGAN } \\
\cline { 3 - 4 } & & AIR (I/ton) & MINYAK (I/ton) \\
\hline 1. & CL-1 & 200 & 60 \\
\hline 2. & CCL-2 & 70 & 10 \\
\hline 3. & CCL-3 & 55 & 5 \\
\hline 4. & CL-4 & 220 & 30 \\
\hline 5. & CL-5 & 210 & 40 \\
\hline 6. & BRJ-1 & 220 & 40 \\
\hline 7. & BRJ-2A & 150 & 50 \\
\hline 8. & BRJ-2B & 170 & 30 \\
\hline 9. & BRJ-3 & 170 & 30 \\
\hline 10. & BRJ-4 & 160 & 40 \\
\hline 11. & BRJ-5 & 170 & 30 \\
\hline 12. & BRJ-6 & 170 & 20 \\
\hline
\end{tabular}


Tabel 8. Hasil analisis petrografi organik

\begin{tabular}{crrrrrrr}
\hline \multirow{2}{*}{ Conto } & \multirow{2}{*}{$\mathrm{RV}_{\max }(\%)$} & $\mathbf{2}$ & $\mathbf{l}$ & $\mathbf{L}$ & Clay & $\begin{array}{c}\text { Oks } \\
\text { Besi }\end{array}$ & Py \\
\cline { 3 - 8 } & & $\mathbf{V}$ & & & & & \multicolumn{3}{c}{ Material mineral (\%) } \\
\hline CL-1 & 0,39 & 90,5 & 0,8 & 2,9 & 5,1 & 0,3 & 0,4 \\
\hline CCL-2 & - & 0,1 & 0,1 & 0,2 & 99,4 & 0,2 & 0,1 \\
\hline CCL-3 & 0,31 & 0,1 & - & 0,1 & 99,4 & 0,4 & 0,2 \\
\hline CL-4 & 0,27 & 96,1 & 0,7 & 1,7 & 1,2 & 0,1 & 0,2 \\
\hline CL-5 & 0,29 & 59,1 & 0,5 & 2,1 & 36,5 & 1,5 & 0,3 \\
\hline BRJ-1 & 0,34 & 88,3 & 3,4 & 2,2 & 5,7 & 0,3 & 0,1 \\
\hline BRJ-2A & 0,32 & 89,6 & 2,3 & 2,6 & 4,9 & 0,5 & 0,1 \\
\hline BRJ-2B & 0,28 & 86,4 & 1,5 & 1,6 & 7,9 & 2,3 & 0,3 \\
\hline BRJ-3 & 0,35 & 94,7 & 1,9 & 1,5 & 1,8 & 0,1 & - \\
\hline BRJ-4 & 0,34 & 90,2 & 2,2 & 2,0 & 5,2 & 0,2 & 0,2 \\
\hline BRJ-5 & 0,32 & 90,8 & 2,8 & 1,7 & 4,1 & 0,4 & 0,2 \\
\hline BRJ-6 & 0,34 & 93,2 & 1,4 & 1,1 & 3,4 & 0,5 & 0,4 \\
\hline
\end{tabular}

Conto Batubara Lahat dan Batubara Baturaja menunjukkan kecenderungan seperti batubara Indonesia pada umumnya yaitu didominasi oleh maseral vitrinit. Perbedaan komposisi terdapat pada conto CL-5 yang memiliki vitrinit sebesar $59,1 \%$. Kemungkinan batubara CL-5 mengandung pengotor yang cukup banyak, hal ini terlihat dari komponen mineral lempung yang mencapai 36,5\%. Conto CCL-2 dan CCL-3 yang merupakan batulempung karbonan tentu saja didominasi oleh mineral lempung $(99,4 \%)$ dengan kandungan liptinit yang sangat sedikit (tidak lebih dari 0,2\%). Hal ini mengkonfirmasi rendahnya kandungan minyak pada kedua conto tersebut yang diperoleh dari analisis pirolisis retort (Tabel 7).

Taylor, et al (1998) menyatakan bahwa karakter batubara yang menguntungkan untuk proses hidrogenasi diantaranya memiliki nilai vitrinite reflectance kurang dari $0,8 \%$ serta komposisi vitrinite + liptinite lebih dari $60 \%$. Seluruhan conto batubara memiliki nilai rata-rata vitrinite reflectance kurang dari $0,8 \%$. Komposisi vitrinite + liptinite seluruh conto batubara juga lebih dari $60 \%$. Berdasarkan karakter petrografi organiknya, maka conto Batubara Lahat dan Baturaja berpotensi untuk diproses dengan metode hidrogenasi (pencairan langsung). Sementara batulempung karbonan (conto CCL-2 dan CCL-3) tidak sesuai untuk hidrogenasi mengingat komposisi vitrinite dan liptinite-nya yang sangat rendah.

\section{KESIMPULAN}

Berbagai analisis yang dilakukan terhadap conto Batubara Lahat dan conto Batubara Baturaja saling mengkonfirmasi satu dan lainnya. Karakter batubara (coal properties) yang diperoleh dari berbagai parameter analisis menunjukkan bahwa Batubara Lahat dan Batubara Baturaja berpotensi sebagai batuan induk yang sangat baik, namun memiliki tingkat kematangan yang belum matang (immature). Pada kondisi matang, batubara tersebut akan cenderung membentuk gas atau sedikit kemungkinan minyak. Sementara itu, conto batulempung karbonan sama sekali tidak menunjukkan karakter sebagai batuan induk dan tidak berpotensi untuk membentuk hidrokarbon. Berdasarkan hasil tersebut maka dapat disimpulkan bahwa Batubara Lahat dan Batubara Baturaja menunjukkan kesesuaian untuk dikonversi menjadi bahan bakar cair.

\section{UCAPAN TERIMA KASIH}

Ucapan terima kasih dihaturkan kepada Ir. Asep Suryana, Ir. Deddy Amarullah dan Wawang Sri Purnomo, ST, yang telah banyak membantu penulis mulai dari akuisisi data sampai ke evaluasi data.

\section{DAFTAR PUSTAKA}

Anonim, 2015. Pemutakhiran Data dan Neraca Sumber Daya Energi. Pusat Sumber Daya Geologi, Bandung, tidak dipublikasikan. 


\section{MAKALAH ILMIAH}

Barber, A.J., Crow, M.J., and Milsom, J.S. (eds.), 2005. Sumatra: Geology, Resources and Tectonic Evolution. Geological Society Memoirs No. 31, The Geological Society, London.

De Coster, G.H., 1974. The Geology of the Central and South Sumatera Basin, Indonesia Petroleum Association, 3 rd Ann. Conv, Proceeding.

Gafoer, S., Corbie, T. dan Purnomo, J., 1986. Peta Geologi Lembar Lahat, Sumatera Selatan. Pusat Penelitian dan Pengembangan Geologi, Bandung.

Harahap, B. H., Bachri, S., Baharuddin, Suwarna, N., Panggabean, H., dan Simanjuntak, T.O., 2003. Stratigraphic Lexicon of Indonesia. Geological Research and Development Centre Special Publication No. 29, Bandung.
Peters, K.E., Moldowan, J.M., (1993). The biomarker guide: Interpreting molecular fossil in petroleum and ancient sediments. Prentice Hall, London. p. 363.

Sapiie, B., Hadiana, M., Nugraha, I., dan Sayentika, 2005. Annalogue Modelling of Rift Mechanism In the Paleogene Graben System of Western Indonesia. Proc. $33^{\text {th }}$ Annual Convention IPA, hal. $593-604$.

Mijnbouw, S., 1978. Explanatory Notes to the Geological Map of the South Sumatera Coal Province, Exploration report.

Suárez-Ruiz, I., and Crelling, J.C. (eds.), 2008. Applied Coal Petrology - The Role of Petrology in Coal Utilization. Academic Press - Elsevier Ltd., USA.

Thomas, L., 2002. Coal Geology. John Wiley \& Sons, England.

\begin{tabular}{|ll|}
\hline Diterima & $:$ 3 Oktober 2016 \\
Direvisi & $:$ 31 Oktober 2016 \\
Disetuiui & $:$ 18 November 2016 \\
\hline
\end{tabular}

